\title{
Relationship between the environmental and hydrogeological elements characterizing groundwater-dependent ecosystems in central Poland
}

\author{
Ewa Krogulec • Sebastian Zabłocki
}

\begin{abstract}
Results are presented for a quantitative and qualitative analysis of the relationship between hydrogeological and environmental elements characterizing the areas of groundwater-dependent ecosytems (GDEs) located in the Kampinos National Park in central Poland. Statistical analysis was used to assess the seasonal and longterm variability of groundwater conditions. A geographic information system (GIS)-based model enabled the visualization of the test results. Objectification of spatial relationships between hydrogeological and environmental elements was carried out using factor analysis. The statistical analysis of groundwater levels in the period 1999-2013 confirmed the sequence of wet and dry years. The calculation enabled the determination of the range of groundwater-level changes, but no specific trends were observed with respect to these changes. Moreover, the widespread belief that the lowering of the water table in presented GDEs is due to anthropogenic pressure and climate change was not confirmed. The factor analysis showed that GDE areas are characterized by a considerable homogeneity of abiotic elements and locally occurring heterogeneous regions, mainly related to anthropogenic pressure. Dependency between the type of plant community and depth to the water table in the typical GDEs was not defined by the delimiting factors.
\end{abstract}

Keywords Groundwater dependent

ecosystem · Groundwater monitoring · Statistics · Factor analysis · Poland

\section{Introduction}

Preservation of existing ecosystems dependent on groundwater (groundwater-dependent ecosystems, GDEs) and renaturalization of selected degraded areas are important elements in most strategies related to the sustainable

Received: 6 November 2014 / Accepted: 13 May 2015

Published online: 21 July 2015

(C) The Author(s) 2015. This article is published with open access at Springerlink.com

E. Krogulec $(\varangle) \cdot$ S. Zabłocki

Department of Geology, 02-089, Warsaw Żwirki i Wigury 93,

Poland

e-mail: ewa.krogulec@uw.edu.pl development and management of water resources. The hydrogeological and environmental elements affecting the condition of GDEs are mainly: regime of infiltration, land use, groundwater extraction, irrigation-discharge networks, and the types and aquatic needs of plant ecosystems. Besides effects of anthropogenic activity, those elements are defined in the literature as a continuous, structured set of relationships: the aquifer-soil-surface water-plant-atmosphere continuum (ASS-PAC; Eamus et al. 2006). The role and importance of each element vary depending on the location of protected ecosystems (Boulton 2005; Boulton and Hancock 2006; Murray et al. 2006; Whiteman et al. 2010; Klove et al. 2011; BaattrupPedersen et al. 2012).

This research conducted in central Poland focused on the quantitative and qualitative analysis of the relationship between hydrogeological and environmental elements characterizing the areas of GDEs (Table 1).

This analysis was primarily used to identify the relationships, and particularly to determine the spatial relationship between the type of plant community and depth to the water table in the GDE areas (Fig. 1). This was made possible through many years of research concerning spatial, seasonal and long-term variability of groundwater conditions, and gathering data about other elements such as soil types, plant communities and spatial development in GDE areas.

GDE areas are characterized by specific types of plant communities with generally high humidity requirements, which can be transposed to groundwater depth. The groundwater level occurrence needed for the existence of particular plant communities in GDE areas is presented in Table 2.

\section{Materials and methods}

\section{Study area}

Studies were conducted in part of the Vistula Valley, a large-sized river of the North European Plain (river length: $1,047 \mathrm{~km}$, size of catchment: $194,424 \mathrm{~km}^{2}$ ). The examined section of the Vistula Valley is located in the Kampinos Forest, part of which is a national park subjected to many forms of conservation protection. Kampinos National Park (KNP) is also an area which is part of the network NATU RA 2000 and Biosphere Reservoir (UNESCO MaB). In 
Table 1 Groups and types of elements characterizing the areas of GDEs

\begin{tabular}{ll}
\hline Group of elements & Type of element \\
\hline Hydrogeological & Average annual groundwater depth for the \\
period 1999-2013 & Groundwater level in 2003 \\
& Groundwater level in 2011 \\
& Average annual amplitude of groundwater \\
& depth for the period 1999-2013 \\
& Infiltration recharge \\
& Hydraulic conductivity of the upper part \\
& of the aquifer (depth $<10 \mathrm{~m}$ ) \\
& Hydraulic conductivity of the deeper part \\
& of the aquifer (depth $>10$ m) \\
& Soil types \\
& Plant community type \\
& Distance from surface watercourses \\
& Lithology of subsurface sediments \\
(unsaturated zone) & X-coordinate location (Longitude of block \\
grid center) & \\
& Y-coordinate location (Latitude of block \\
& grid center)
\end{tabular}

accordance with the requirements of the UNESCO programme, the reservoir has three zones: central, buffer and transit. The central zone, called the core, encompasses areas of Kampinos National Park under strict protection, with adjacent territories which are valuable in terms of nature. The most important function of the KNP is the protection of natural resources and natural processes.

Kampinos National Park, established in 1950, takes up an area of $385 \mathrm{~km}^{2}$ that is surrounded by a protective zone established in 1977 (called a lagging) with an area of $378 \mathrm{~km}^{2}$. The park and its lagging is bordered in the north and north-east by the Vistula River; in the east, the border runs through suburbs of Warsaw, in the south it runs through agricultural areas of the Lowicz-Błonie Plain (Błonie level); while in the west, the left shore of Bzura River constitutes the border (Fig. 1).

The hydrogeological conditions of KNP have been the subject of several research projects, including Project 2011-2014 "Model analysis of hydrogeological conditions in wetlands" (The State Committee for Scientific Research) and Project 2008-2011 "Development of the method for reconstruction of primary hydrological conditions in Kampinos National Park in order to restrain nature degradation and improve biodiversity status" (EEA Financial Mechanism and the Norwegian Financial Mechanism), and are summarized in several publications (Krogulec 2003a, b, 2004; 2013; Krogulec et al. 2009, 2011). The following criteria were used to distinguish

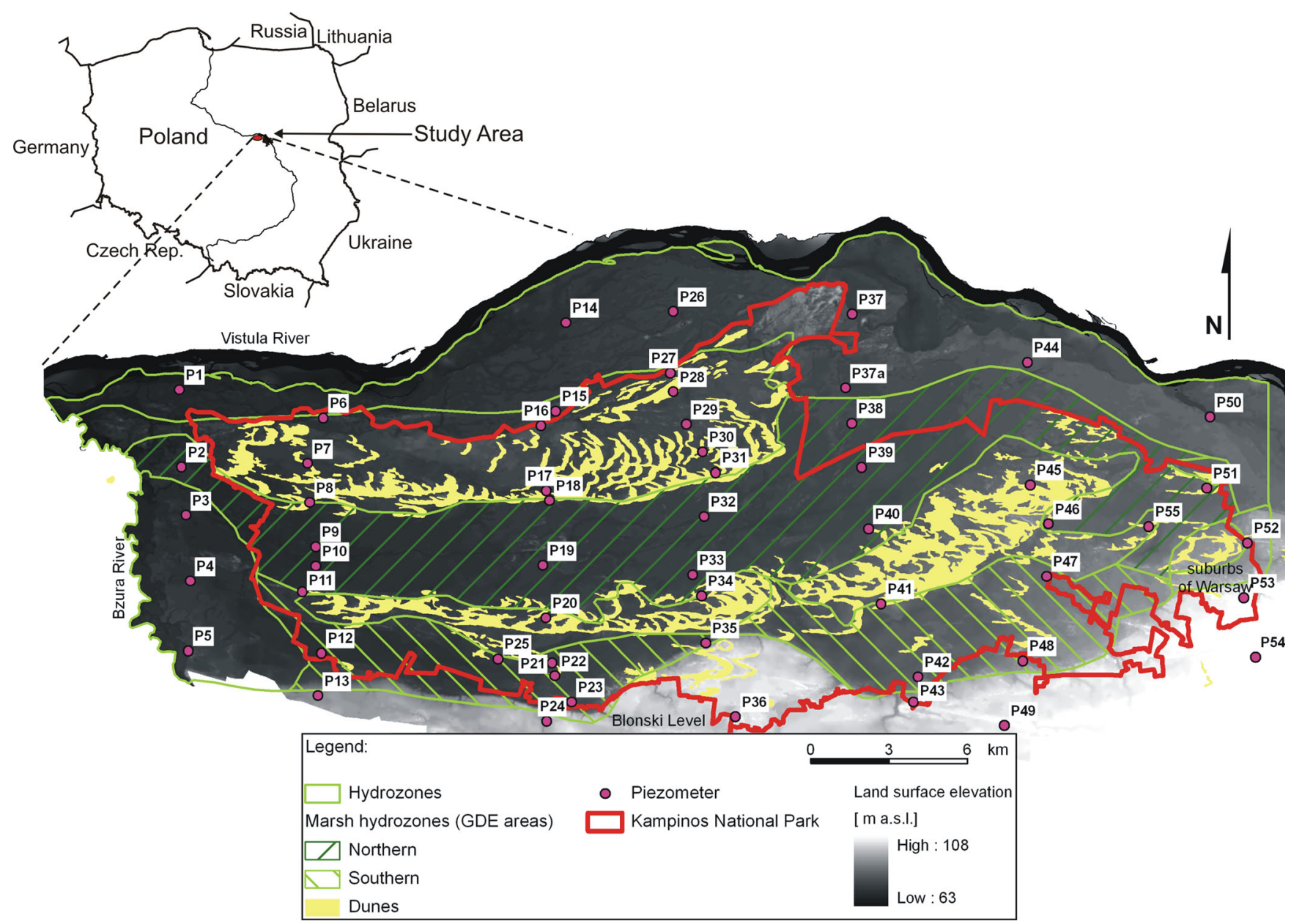

Fig. 1 Location of the GDE areas on the background of the Kampinos National Park

Hydrogeology Journal (2015) 23: 1587-1602

DOI $10.1007 / \mathrm{s} 10040-015-1273-y$ 
Table 2 Types of plant communities occurring in GDE areas and their general humidity requirements (Kloss 2003a, b; Kucharski and Michalska-Hejduk 2003)

\begin{tabular}{ll}
\hline Plant communities & Humidity requirements of plant communities \\
\hline $\begin{array}{l}\text { Sparganio-Glycerietum fluitantis, Phragmitetum communis, } \\
\text { Glycerietum maximae, Phragmition }\end{array}$ & Surface waters \\
$\begin{array}{l}\text { Ribeso nigri-Alnetum, Vaccinio uliginosi-pinetum, Magnocaricion, } \\
\text { Scheucherio-Caricetea fuscae, Salicetum pentandro-cinereae, }\end{array}$ & Water should occur above ground surface for most of the year \\
Cercatalia fuscae & \\
Fraxino-Alnetum, Molinion ceruleae, Calthion & $\begin{array}{c}\text { Water should occur to } 0.5 \mathrm{~m} \text { below ground surface, with } \\
\text { possibly short period of occurrence above ground surface } \\
\text { Water should occur near ground surface, with possibly autumn } \\
\text { dilio-Carpinetum, Arrhenatherion }\end{array}$ \\
\end{tabular}

zones of similar hydrodynamic and environmental conditions, known as the so-called hydrozones (Krogulec 2004): differences in geologic structure and geomorphology, lithology of subsurface sediments and related vegetation cover, depth to the water table, amplitude of water level fluctuations and human economic activities. The following hydrozones have been distinguished in the KNP area:

- The Vistula River flood plain terrace

- Two marsh zones (northern and southern)

- Two dune zones (northern and southern)

- An accumulative-erosive Warsaw-Blonie terrace called the Blonski level (with part of the upland)

Quaternary sediments occur in the entire area of the park and lagging, constituting a collector for groundwater. A clear dichotomy of this unconfined aquifer, of a total thickness up to $50 \mathrm{~m}$, is connected with its lithological shape. The top part of the aquifer has a sandy and sandygravel character; the bottom is created by sandy-silt sediments, in places changing to sandy clay, clay and till. The surface of the aquitard created by glacial tills and more often Pliocene loams, constituting the floor of the Quaternary aquifer, occurs in the region of KNP at elevations ranging from 2 to $54 \mathrm{~m}$ above sea level (a.s.l.; Baraniecka and Konecka-Betley 1987; Sarnacka 1992; Krogulec et al. 2003; Fig. 2). Delimitation of the main groundwater circulation systems in the Quaternary aquifer was made by Krogulec (2004) following the methods of Tóth (1963). Although general flow direction in the aquifer is north and west to the main discharge base, i.e. the Vistula and Bzura rivers (intermediate system), groundwater circulation in GDE areas should be considered as a local system (Fig. 3). The influence of river stage on the aquifer is very limited (around $1 \mathrm{~km}$ ), so the groundwater system in GDE areas can be viewed as independent. For the purposes of evaluation of the water balance in the Quaternary aquifer by model tests (Gruszczyński and Krogulec 2012), the groundwater system was limited from the north by the Vistula River, from the west by the Bzura River, and from the south along the edge of Blonski Level, while the eastern boundary runs along the border of the city of Warsaw. The bottom surface of the model was determined by weakly permeable deposits occurring in the base of the alluvia. More detailed characteristics of groundwater conditions are presented in the following.

\section{Methodology}

The methodology was designed to create a database describing spatial variability of all hydrogeological and environmental elements characterizing GDE areas.

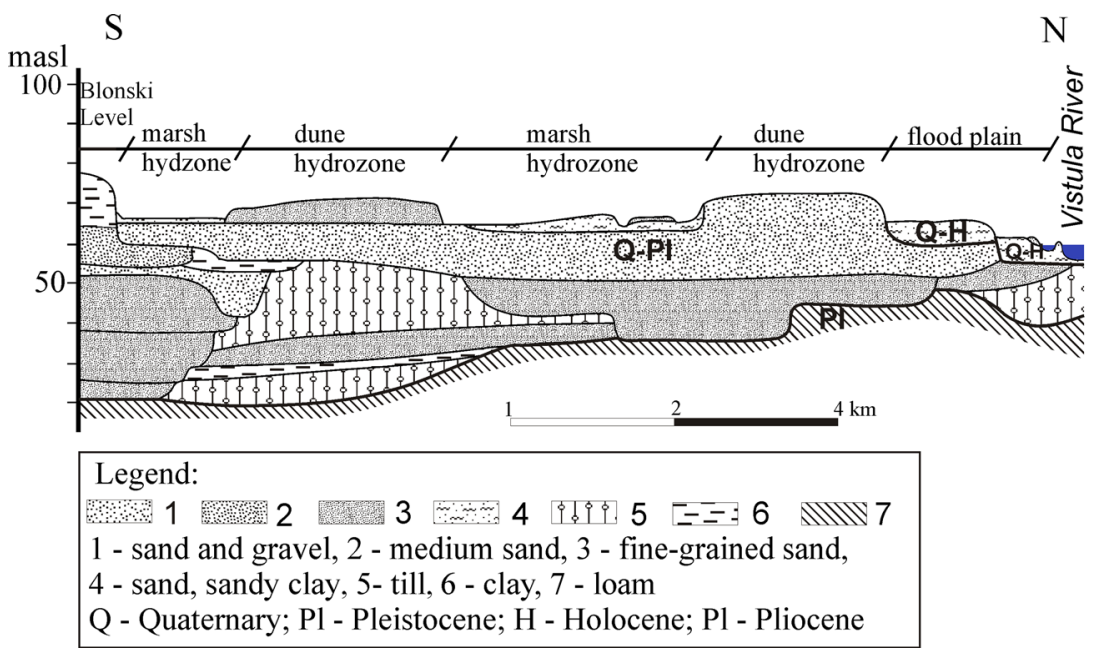

Fig. 2 Schematic cross-section of Quaternary sediment in the area of the Kampinos National Park

Hydrogeology Journal (2015) 23: 1587-1602 


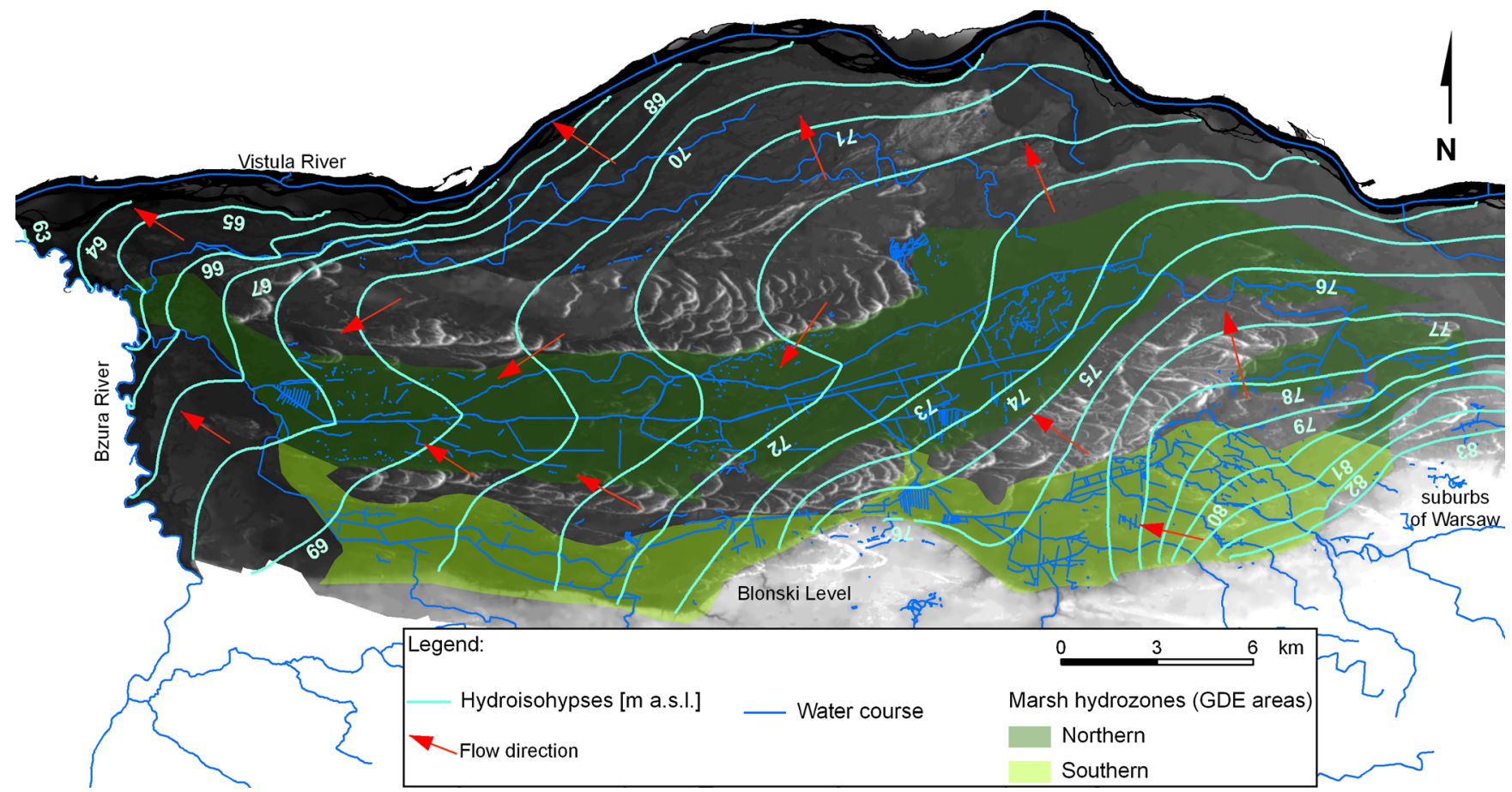

Fig. 3 Hydroisohypses of the Quaternary aquifer feeding GDE areas in KNP: results of groundwater flow model, as the average annual state during the period 1999-2013

Several steps were needed, as shown on Fig. 4 , to set up the database as the input file for factor analysis. The first step was the analysis of data from the groundwatermonitoring network in KNP, which enabled the evaluation of trend changes at points and the identification of specific statistical data. The basis of the analysis was a set of data from the period 1999-2013, which provided over 7,500 observations referring to 27 observation points located in the GDEs. The statistical analysis of those monitoring observations most widely used in monitoring networks (Loaiciga et al. 1992; Moon et al. 2004; Bidwell 2005; Coppola et al. 2005; Krogulec and Zabłocki 2008; Yang et al. 2008; Baalousha 2010; Maheswaran and Khosa
2013; Shiri et al. 2013) was the basis for identifying the range of seasonal, annual and long-term groundwater level changes.

Assessment of the quantitative state of groundwater was carried out using spatial statistical analyses as well as numerical groundwater flow modeling; the GIS-based model, made by using the Visual MODFLOW software package, was employed as a tool, which is commonly used to visualize test results in hydrogeology and ecology (Olivera and Maidment 1999; Gogu et al. 2001; Store and Kangas 2001; Babiker et al. 2005; Baker et al. 2001).

The spatial interpretation of the hydrogeological data was carried out using the GIS software. The analysis was

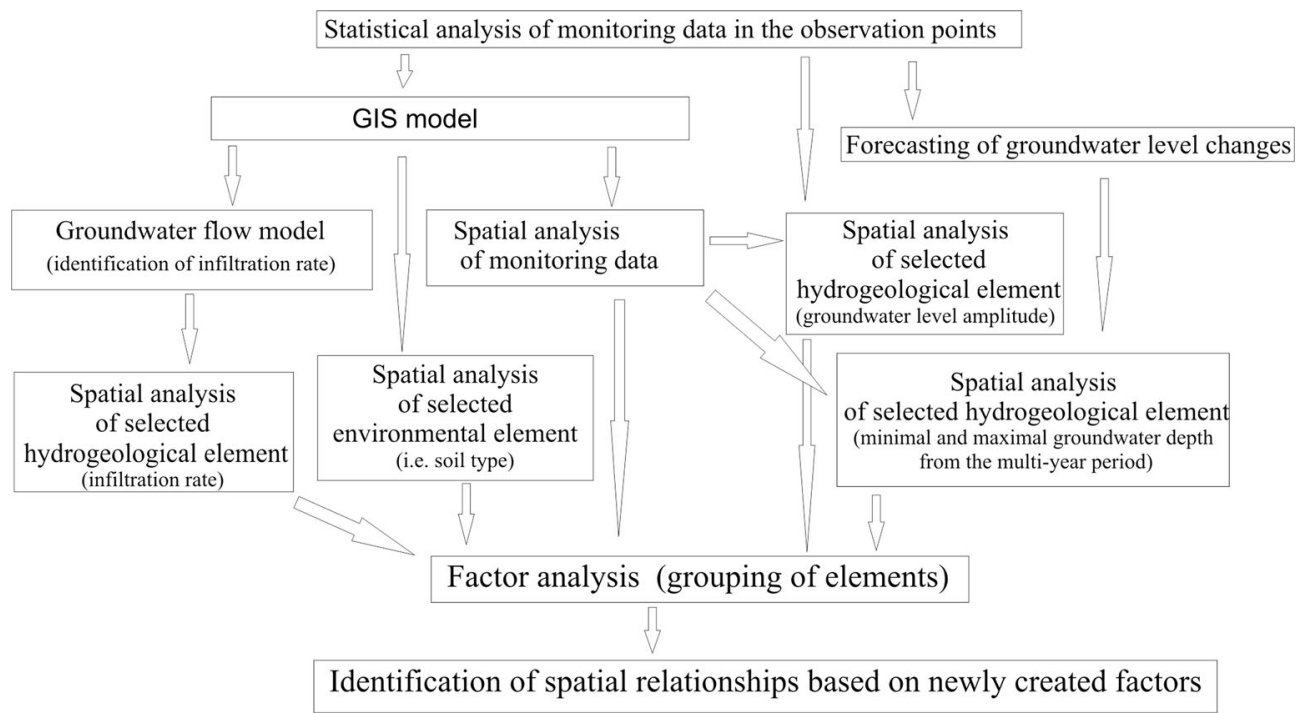

Fig. 4 Evaluation methodology of spatial relationships between hydrogeological and environmental elements in the GDE areas 
conducted with the Kriging method, which involved data derived from the monitoring network (SikorskaMaykowska et al. 1998). Uncertainty of the method results was checked by comparing groundwater-flowmodel results representing steady state. In the case of particular groundwater levels (2003, 2011), computed mean square errors were lower than the mean square error of estimation in the groundwater flow model $(0.167 \mathrm{~m})$. The result of the spatial distribution of average annual groundwater level from period 1999-2013 was compared also to the results of the groundwater flow model. In the area of $105.67 \mathrm{~km}^{2}$, which is $43.63 \%$ of GDE areas, the mean square error of statistical distribution was lower than $0.167 \mathrm{~m}$. The highest discrepancy was found on the southern and eastern border of GDE areas $(>1 \mathrm{~m})$.

The study area was digitized by adopting a discretization space step size (grid size) of $0.01 \mathrm{~km}^{2}$ $(100 \times 100 \mathrm{~m})$, and in this way the 23,814 blocks of the discretization grid were obtained. The adopted step size corresponds to the resolution of the digital elevation model and the accuracy of hydrogeological, geological and environmental reconnaissance. The continuous data (i.e., soil types, plant communities) were transformed into point observations located in the block center representing the dominant type of data occurring in the particular grid. Also discrete data were input into the factor analysis. Each discretization cell had same attributes: hydrogeological and environmental (Table 3 ).

The next step of research was factor analysis. The hydrogeological and environmental elements in a database enable factor analysis to be performed in order to objectify the spatial relationships between the elements that describe the hydrological system (Joreskog et al. 1976; Reyment and Joreskog 1993; Liszkowska 1995; Gangopadhyay et al. 2001; Dragon 2002; Stępień 2004). To extract the most important factors in the factor analysis and to group them into hydrogeological and environmental elements, principal component analysis (PCA) was conducted by using Statistica 10.0 software. The PCA method is most commonly used to reduce the size of a database by extracting those factors explaining the largest part to explain the smallest part of the variance in a newly established coordinate system (Bryant and Atchley 1975; Jolliffe 2002). Thus, the purpose of using this method was, first of all, to categorize hydrogeological and environmental elements in a 23,814-block grid describing the study area. The ranking is given to particular elements according to the precisely gathered information about the aquifer and the range of its variability in the presented area, making this also a subjective assessment, which is why the hydrogeologist's role in this procedure is so important. The data such as the soil type, lithology of subsurface sediments creating an unsaturated zone and plant communities, were replaced by numerical values of a ranking system in the range 1-10 using a procedure similar to the ranking procedure used in the assessment of groundwater vulnerability to pollution (Aller et al. 1987; Krogulec 2004). In the case of soil types and lithology of subsurface sediments, lower rankings generally indicate

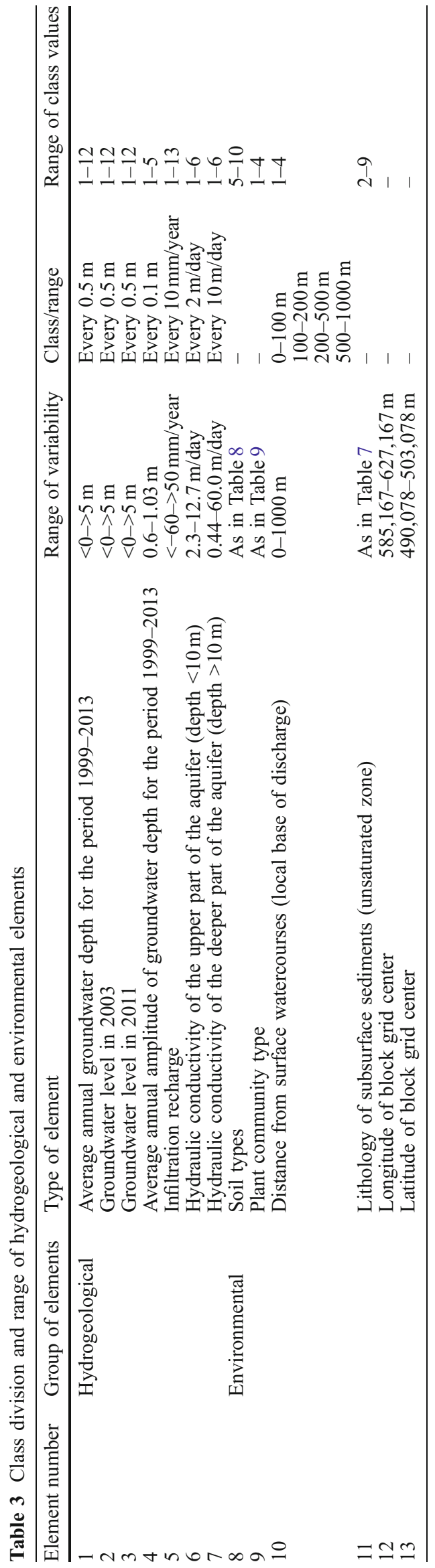

DOI 10.1007/s10040-015-1273-y 
higher resistance to pollutant migration from the ground surface and a lower value of hydraulic conductivity; in the case of plant communities, the lowest rank informs about the relatively lower humidity requirements compared with the other groups. Based on the range of variability of particular hydrogeological elements, division into classes was also made.

All the data were standardized and transformed to the log-normal distribution in the case of skew distribution defined on the basis of the Kolmogorov-Smirnov test (Joreskog et al. 1976). The correlation matrix indicated high correlation between some elements (i.e., groundwater depth vs. infiltration recharge), so only seven major and four auxiliary elements were selected for further analysis. This step allowed for reduction of potentially created new factors from 13 elements (Table 3 ) to 7 before analysis was started. For element Nos. 2 and 3, groundwater levels in 2003 and 2011 (Table 3) were also excluded from analysis due to the high Pearson correlation with element No. 1. Factors with the lowest factor loadings were rejected, while for the strongest factors distinguished by the Scree test (Cattell 1966), interpretation was made on the basis of the strength of correlation between particular elements.

\section{Characteristics of selected hydrogeological and environmental elements}

There were 13 elements used that describe the GDE areas. Detailed characteristics of selected elements are presented. Selected elements were chosen with reference to (1) the gathered data from the groundwater-monitoring network and previously presented water balance from the groundwater flow model (groundwater depth; infiltration recharge) and (2) character of the data and their spatial variability (qualitative data such as soil type, plant communities and the lithology of subsurface sediments). Information about the other elements and main characteristics are presented in Table 3.

\section{Statistical analysis of groundwater levels}

Statistical analysis of groundwater levels in both marsh hydrozones included basic statistics for both the 19992013 period and particular years: mean, median, standard deviation, first quartile, third quartile, max, min, max amplitude, average amplitude. On the basis of these data, seasonal changes were analyzed and the scope of groundwater levels was defined. For both hydrozones a distinct characterization was established, highlighting their diversity despite their close, shared neighborhoods.

In the northern marsh hydrozone, the average annual groundwater level for the period 1999-2013 remained at the level of $0.91 \mathrm{~m}$ below the ground surface (Fig. 5). The average annual groundwater level in this period ranged from $0.47 \mathrm{~m}$ below ground surface (bgs) in 2011 to $1.14 \mathrm{mbgs}$ in 2003. Groundwater levels such as $0.40 \mathrm{~m}$ above ground surface (2011) and $2.16 \mathrm{mbgs}$ (2003), define the range of recorded measurements and, because of the long period of observation, it can be assumed that this range approximately determines the groundwater levels which can be observed in this environment.

Seasonal changes proceeded in a similar manner throughout the measurement period. The highest average groundwater level in the hydrozone occurs in the period associated with groundwater recharge linked to thawing in

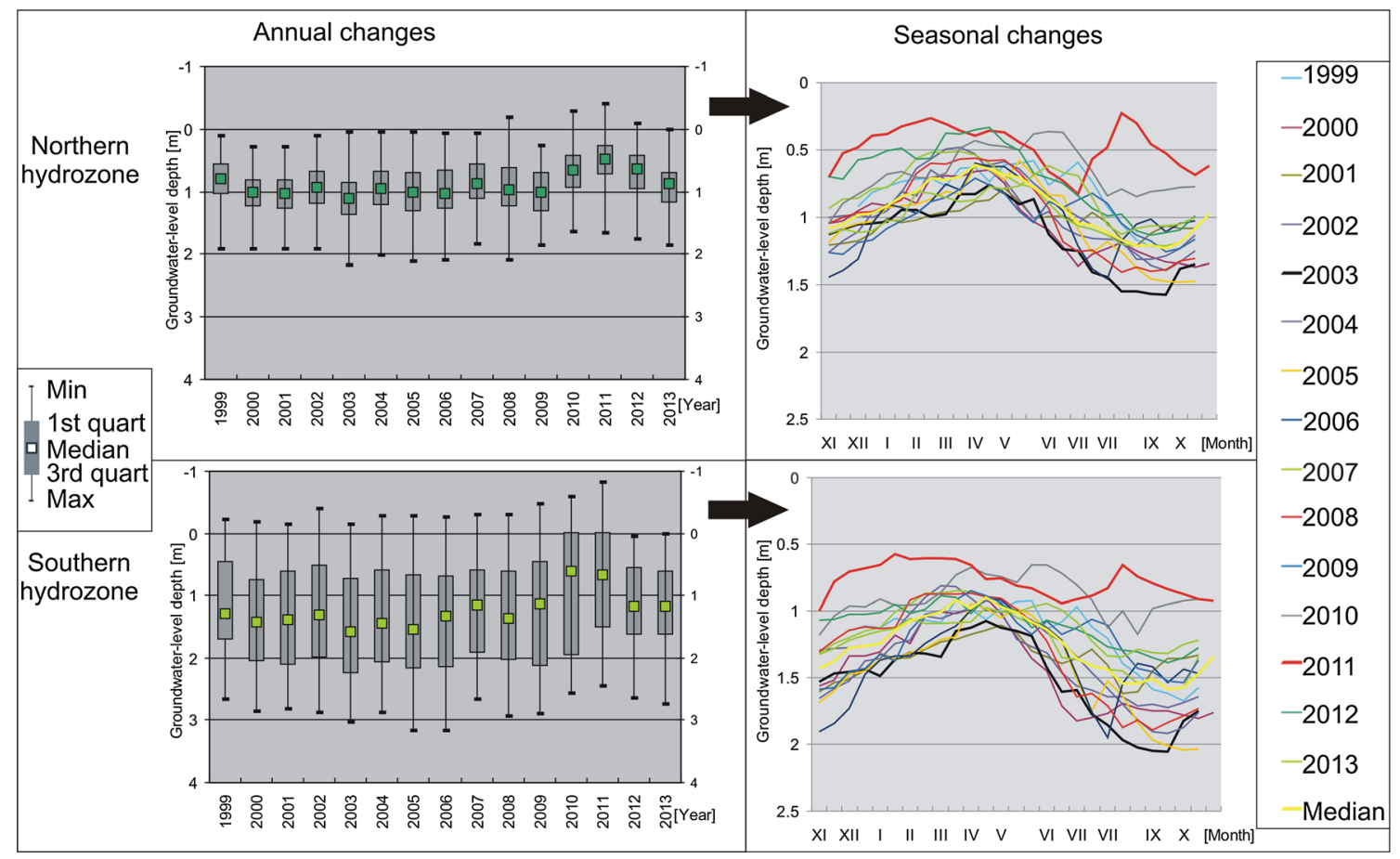

Fig. 5 Multi-year and seasonal groundwater-level changes in the GDEs areas 
Table 4 Statistics related to depth to groundwater in the marsh hydrozones based of the spatial distribution: average annual groundwater level for the period 1999-2013

\begin{tabular}{lll}
\hline & Northern hydrozone & Southern hydrozone \\
\hline Area $\left[\mathrm{km}^{2}\right]$ & 155.68 & 86.62 \\
Depth to groundwater $[\mathrm{mbgs}]$ & \\
Average & 1.03 & 1.68 \\
Median & 0.90 & 1.20 \\
Max depth & 10.10 & 10.95 \\
Min depth & $0.60 \mathrm{ags}$ & $1.10 \mathrm{ags}$ \\
First quartile & 0.40 & 0.49 \\
Third quartile & 1.54 & 2.29 \\
SD & 1.01 & 1.97 \\
Skewness & 2.43 & 1.75 \\
\hline
\end{tabular}

mbgs meters below ground surface (except where highlighted as ags); ags above ground surface; $S D$ standard deviation

the months from February to April, when the groundwater level is at a depth of about $0.5 \mathrm{mbgs}$ (Fig. 5). The lowest groundwater level occurs in late summer and autumn (from 15.09 to 15.10 ) and on average ranges from 1 to $1.5 \mathrm{mbgs}$ in the hydrozone depending on the year. Only the year 2011 marked two periods of the highest groundwater level: February-March and AugustSeptember. Seasonal changes in the depth of groundwater in the hydrological year 2004 are the most similar to the average seasonal changes in the 1999-2013 period (median). In the southern marsh hydrozone, the average depth to groundwater for the period 1999-2013, i.e., $1.24 \mathrm{mbgs}$ is slightly higher than those in the northern hydrozone. The average annual groundwater levels range from $0.77 \mathrm{mbgs}$ (2011) to $1.52 \mathrm{mbgs}$ (2003) (Fig. 5). The range of measurements that have been previously reported determine the groundwater levels: $0.83 \mathrm{~m}$ above ground surface (2011) and $3.17 \mathrm{mbgs}$ (2006). Seasonal changes proceeded in a similar manner for all years of the period 1999-2013. The highest average groundwater level occurs in April when the groundwater level is at an average depth of about $0.8-1.2 \mathrm{mbgs}$ (Fig. 5). The lowest groundwater

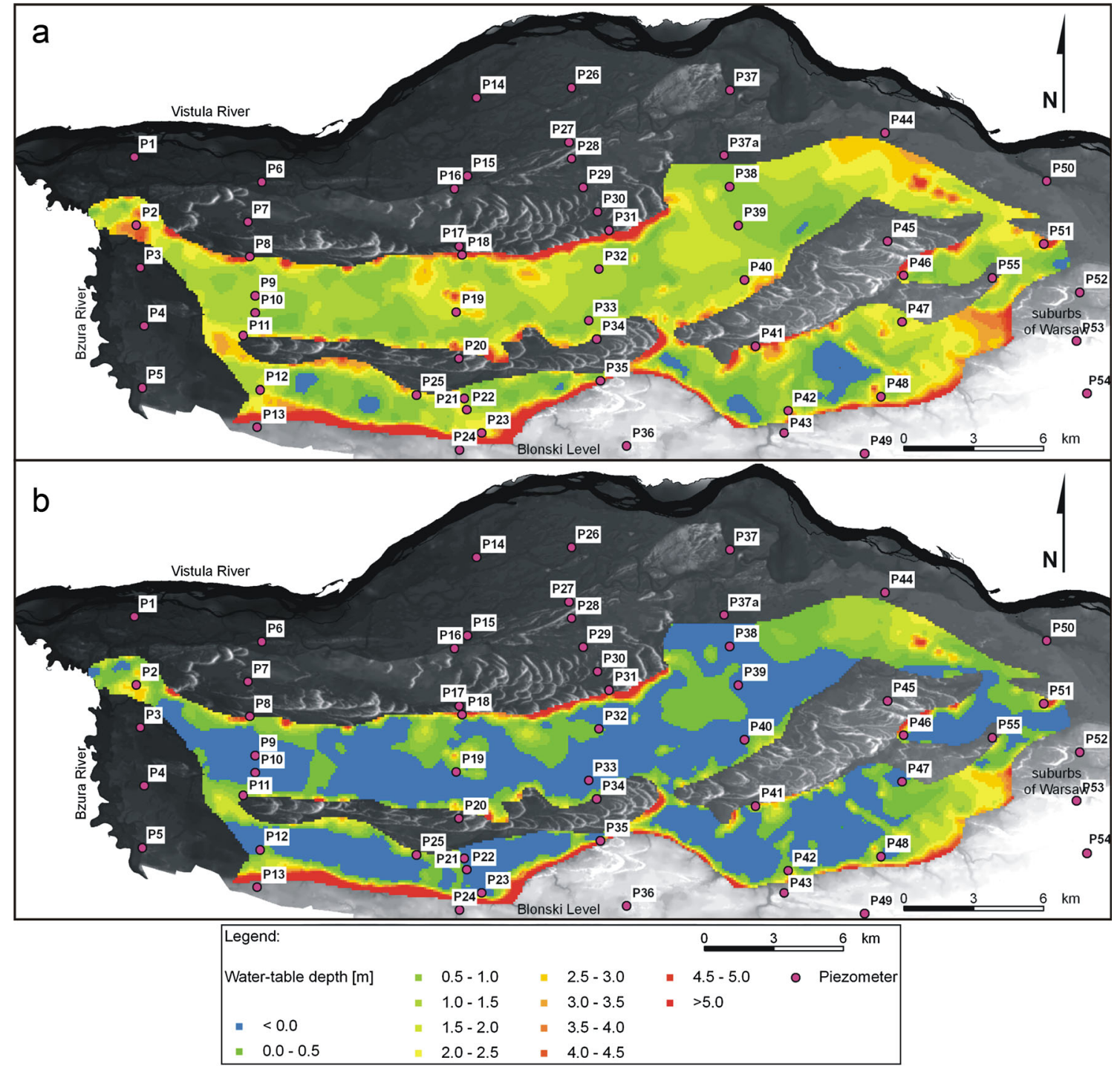

Fig. 6 Contours of water-table depth: a maximum depth in year 2003; b minimum depth in year 2011 
Table 5 Water balance in the marsh hydrozones

\begin{tabular}{|c|c|c|c|c|}
\hline \multirow[t]{2}{*}{ Element of the balance } & \multicolumn{2}{|c|}{ Northern marsh zone } & \multicolumn{2}{|c|}{ Southern marsh zone } \\
\hline & Supply $\left[\mathrm{m}^{3} /\right.$ day $]$ & Discharge $\left[\mathrm{m}^{3} /\right.$ day $]$ & Supply [m³/day] & Discharge $\left[\mathrm{m}^{3} /\right.$ day $]$ \\
\hline Exploitation & 0.0 & 0.0 & 0.0 & 476.2 \\
\hline Watercourses & 750.8 & 10029.8 & 2007.9 & 3753.5 \\
\hline Underground evaporation & 0.0 & 23707.0 & 0.0 & 11651.0 \\
\hline Inflow through the model boundary & 0.0 & 0.0 & 11312.0 & 0.0 \\
\hline Infiltration recharge & 19405.0 & 0.0 & 11877.0 & 0.0 \\
\hline Supply from other hydrozones & 21275.0 & 7996.6 & 1296.5 & 11960.4 \\
\hline Total & 41736.0 & 41733.0 & 27841.0 & 27841.1 \\
\hline
\end{tabular}

level occurs earlier than in the northern marsh hydrozonelate August and September - and the average depth to groundwater is approximately $1.5 \mathrm{mbgs}$ (two periods in 2011: summer and in winter). Seasonal changes in the depth of groundwater in the hydrological year 2007 (this year is classified as wet) are the most similar to average seasonal changes in the 1999-2013 period (median). As in the northern marsh hydrozone, a range of average seasonal changes mainly determines the groundwater levels in 2003 and 2011.

\section{Spatial analysis of groundwater levels}

Based on the results of the statistical analysis of monitoring data from the period 1999-2013, the 2 years 2003 and 2011 were selected. These years illustrate the lowest and highest values of groundwater levels in the period. On the basis of measurements from these years, maps of the contours of the maximum (2003) and minimum (2011) depth to groundwater level were drawn (Table 4; Fig. 6).

In 2003 , in the northern marsh hydrozone, average annual groundwater depth was $0.31 \mathrm{~m}$ lower than the average from the period 1999-2013, and in the southern hydrozone it was $0.56 \mathrm{~m}$ lower. In 2011, in both hydrozones it reached $0.80 \mathrm{~m}$ higher than the long-term average.

During the lowest state (2003) groundwater above ground surface occurred over an area of $0.39 \mathrm{~km}^{2}$, mainly in natural denivelations along the Lasica channel (northern hydrozone), and over an area of $6.58 \mathrm{~km}^{2}$ in the southern hydrozone. The highest state (2011) is characterized by groundwater occurrence above ground surface over an area of $81.43 \mathrm{~km}^{2}$ (northern hydrozone), and $40.1 \mathrm{~km}^{2}$ in the southern hydrozone.

\section{Infiltration recharge}

The groundwater flow model enabled the calculation of the groundwater balance of the analyzed hydrogeological system. The balance was made in steady-state conditions defined as average annual state, consisting of the total inflow and outflow throughout the study area, which involves the park and delimited hydrozone area (Gruszczyński and Krogulec 2012). The water-bearing system has been represented by means of an orthogonal discretization grid with a step of $\Delta x=\Delta y=100 \mathrm{~m}$. A detailed description of this model-based research has been presented in several publications (Krogulec 1997; Gruszczyński and Krogulec 2012). The result of the model calculations was the water balance for marsh hydrozones (Table 5) and an infiltration grid, which, in a discrete way, represents the spatial distribution of infiltration recharge of the aquifer system as average annual recharge. The analysis of the discrete data enabled the development of an isoline image and data statistics.

The marsh hydrozones are characterized by the occurrence of a typical relationship in which evaporation from a shallow aquifer exceeds the annual effective infiltration in the annual balance (Soczyńska et al. 2003). Average infiltration for the area of the northern marsh hydrozone is approximately $-12 \mathrm{~mm} /$ year (negative value indicates evaporation), while in the southern hydrozone it is about $2 \mathrm{~mm} / \mathrm{year}$ (data from the groundwater flow model). The lowest values for infiltration occur along the axis of both marsh hydrozones and reach a minimum below $-60 \mathrm{~mm} / \mathrm{year}$ (Table 6), while the highest values are found along the borders of both hydrozones, in the vicinity of dune areas or the Blonski Level $(>60 \mathrm{~mm} /$ year; Fig. 7). The areas where the infiltration process ranges from -30 to $-20 \mathrm{~mm} /$ year are the most populous in the northern hydrozone (over $10 \%$ of the area). In the area of the southern hydrozone, the most common range of infiltration is $30-40 \mathrm{~mm} /$ year (about $10 \%$ of the area).

Table 6 Infiltration recharge in the marsh hydrozones

\begin{tabular}{|c|c|c|c|c|c|}
\hline \multirow[t]{2}{*}{$\begin{array}{l}\text { Range of class } \\
\text { values [mm/year] }\end{array}$} & \multirow[t]{2}{*}{ Class No. } & \multicolumn{2}{|c|}{$\begin{array}{l}\text { Northern } \\
\text { marsh zone }\end{array}$} & \multicolumn{2}{|c|}{$\begin{array}{l}\text { Southern } \\
\text { marsh zone }\end{array}$} \\
\hline & & $\begin{array}{l}\text { Area } \\
{[\%]}\end{array}$ & $\begin{array}{l}\text { Area } \\
{\left[\mathrm{km}^{2}\right]}\end{array}$ & $\begin{array}{l}\text { Area } \\
{[\%]}\end{array}$ & $\begin{array}{l}\text { Area } \\
{\left[\mathrm{km}^{2}\right]}\end{array}$ \\
\hline$<-60$ & 1 & 8.82 & 13.74 & 9.55 & 8.28 \\
\hline-60 to -50 & 2 & 7.82 & 12.17 & 5.84 & 5.06 \\
\hline-50 to -40 & 3 & 9.63 & 14.99 & 6.15 & 5.33 \\
\hline-40 to -30 & 4 & 9.59 & 14.93 & 6.39 & 5.54 \\
\hline-30 to -20 & 5 & 10.23 & 15.94 & 6.87 & 5.95 \\
\hline-20 to -10 & 6 & 9.78 & 15.23 & 6.64 & 5.75 \\
\hline-10 to 0 & 7 & 9.22 & 14.35 & 6.54 & 5.66 \\
\hline $0-10$ & 8 & 7.91 & 12.31 & 8.28 & 7.17 \\
\hline $10-20$ & 9 & 5.70 & 8.87 & 7.17 & 6.21 \\
\hline $20-30$ & 10 & 4.87 & 7.58 & 8.79 & 7.61 \\
\hline $30-40$ & 11 & 4.75 & 7.39 & 10.50 & 9.11 \\
\hline $40-50$ & 12 & 5.98 & 9.31 & 9.18 & 7.95 \\
\hline$>50$ & 13 & 5.69 & 8.86 & 8.08 & 7.00 \\
\hline
\end{tabular}

DOI 10.1007/s10040-015-1273-y 


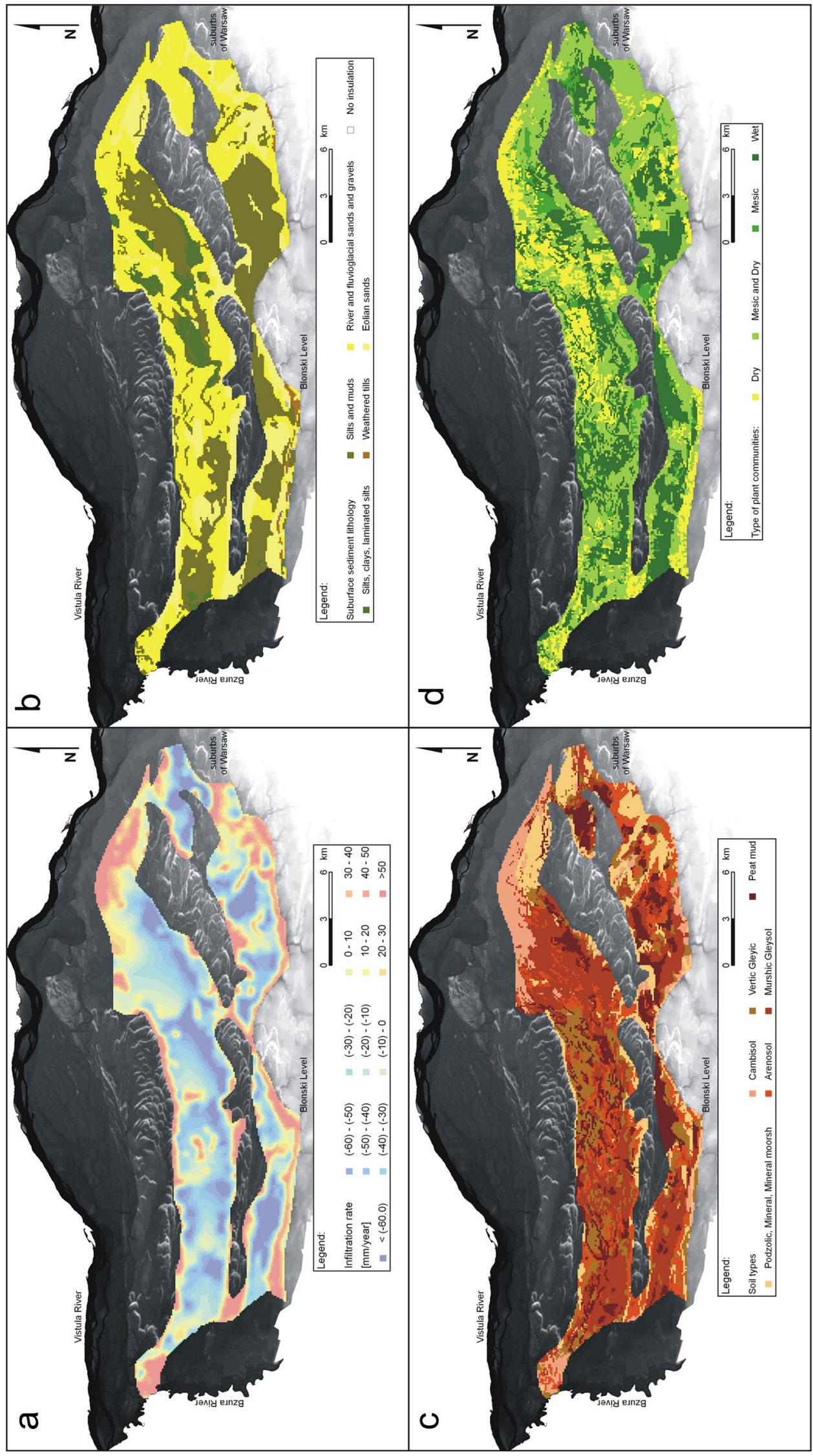

Fig. 7 Selected hydrogeological (a-b) and environmental elements (c-d): a infiltration rate; b subsurface sediment lithology; c soil type; d type of plant communities 
Table 7 The lithology of subsurface sediments (unsaturated zone) in the marsh areas

\begin{tabular}{|c|c|c|c|c|c|}
\hline \multirow[t]{3}{*}{ Lithology of subsurface sediments } & \multicolumn{4}{|l|}{ Area } & \multirow[t]{3}{*}{ Class No. } \\
\hline & \multicolumn{2}{|c|}{ Northern hydrozone } & \multicolumn{2}{|c|}{ Southern hydrozone } & \\
\hline & {$[\%]$} & {$\left[\mathrm{km}^{2}\right]$} & {$[\%]$} & {$\left[\mathrm{km}^{2}\right]$} & \\
\hline Silts, clays, laminated silts & 8.35 & 13.00 & 0.39 & 13.00 & 2 \\
\hline Silts and muds & 24.63 & 38.34 & 46.92 & 38.34 & 3 \\
\hline Weathered tills & 0.02 & 0.03 & 2.14 & 0.03 & 4 \\
\hline River and fluvioglacial sands, gravel & 51.89 & 80.78 & 21.93 & 80.78 & 8 \\
\hline Eolian sands & 15.11 & 23.52 & 28.09 & 23.52 & 9 \\
\hline Areas with no insulation, surface water & 0.00 & 0.00 & 0.53 & 0.00 & 9 \\
\hline
\end{tabular}

\section{Subsurface sediment lithology}

The lithology of subsurface sediments (unsaturated zone) in the marsh areas is characterized by considerable variability. In the northern marsh hydrozone, the largest part of the area (approximately $52 \%$ ) is comprised primarily of river sediments (Baraniecka and KoneckaBetley 1987) such as sand and gravel (Table 7); however, the layer of river sediments is more differentiated, because of the occurrence of different types of organic matter in the subsurface part of the layer. The unsaturated zone (an area of approximately $38 \mathrm{~km}^{2}$, which is $25 \%$ of northern marsh hydrozone) consists of only silts and muds. Within the southern marsh hydrozone, these kinds of sediments occur over approximately $41 \mathrm{~km}^{2}$ and comprise a dominant class $(47 \%)$, at the expense of river and fluvioglacial sands $(22 \%)$. There are also eolian sands within the marsh hydrozones (15-28\% of the surface), which are morphological forms locally elevated in relation to the surrounding depression with no outflow or watercourses. The sands limit the marsh hydrozones to the north and south, but also occur in the central parts, being frequently bisected by a network of channels (Fig. 7).

\section{Soils}

Two soil maps of the study area, the first one showing primary soil cover (Wicik 1995) and the second one showing the present soil cover (Piórkowski et al. 2011) were used. For the purpose of this study, a generalized map was used (Table 8; Fig. 7). The least-molded inorganic soils such as mineral moorsh, mineral, and podzolic soils, can be found in the marsh hydrozones, but only over about $10-21 \%$ of the area (Table 8 ). The soils, in which during the process of creation an important role is played

Table 8 Soil types in the marsh hydrozones (Wicik 1995; Piórkowski et al. 2011; generalized)

\begin{tabular}{|c|c|c|c|c|c|}
\hline \multirow[t]{3}{*}{ Soil types } & \multicolumn{4}{|l|}{ Area } & \multirow{3}{*}{$\begin{array}{l}\text { Class } \\
\text { No. }\end{array}$} \\
\hline & \multicolumn{2}{|c|}{$\begin{array}{l}\text { Northern } \\
\text { hydrozone }\end{array}$} & \multicolumn{2}{|c|}{$\begin{array}{l}\text { Southern } \\
\text { hydrozone }\end{array}$} & \\
\hline & [\%] & {$\left[\mathrm{km}^{2}\right]$} & $\overline{[\%]}$ & {$\left[\mathrm{km}^{2}\right]$} & \\
\hline $\begin{array}{l}\text { Mineral moorsh, } \\
\text { mineral, podzolic soil }\end{array}$ & 10.61 & 16.52 & 21.18 & 18.35 & 10 \\
\hline Cambisol & 11.05 & 17.20 & 5.69 & 4.93 & 9 \\
\hline Arenosol & 12.28 & 19.12 & 18.38 & 15.92 & 8 \\
\hline Vertic Gleyic & 14.24 & 22.17 & 12.25 & 10.61 & 7 \\
\hline Murshic Gleysol & 35.88 & 55.86 & 25.96 & 22.49 & 6 \\
\hline Peat mud & 15.73 & 24.49 & 16.53 & 14.32 & 5 \\
\hline
\end{tabular}

Hydrogeology Journal (2015) 23: 1587-1602 by the depth to groundwater, occupy the largest area. These are mainly swampy soils (peat mud) - about $15 \%$ of the area in both hydrozones; Arenosol and Vertic Gleyic comprise approximately 12-18\%. Murshic Gleysols, which occupy the largest area $(35 \%)$ of the northern hydrozone (Fig. 7) and 26\% of the southern hydrozone area, are the result of swampy soil degradation as a result of the process of an improperly functioning melioration network.

\section{Ecosystems}

On the basis of the actual vegetation map (Wicik 1995) and based on the results of the monitoring of vegetation carried out in 2007 in selected areas of the marsh hydrozones (Michalska-Hejduk et al. 2011; Kopeć et al. 2013, 2013, Krogulec 2013), the four types of plant communities were delimited according to their relative humidity (Table 9). In swampy areas, most types of plant communities refer to both soil types and relief, so that the relationship between the type of vegetation and depth to water table should also be noticeable. The largest spatial variability of plant communities can be found in the northern marsh hydrozone. In the north-eastern part of this hydrozone, there are the biggest areas where plant communities were classified as dry. The total contribution of these types of communities is approximately $20 \%$ of the northern marsh hydrozone. Typical wet communities occur over $46.77 \mathrm{~km}^{2}$, which represents approximately $30 \%$ of the area.

In the southern marsh hydrozone, the plant communities form more compact spatial compositions (Fig. 7). In the eastern part, the mesic and dry communities dominated and occupy a total area of around $43 \%\left(37.58 \mathrm{~km}^{2}\right)$. Communities which are typically dry, are found in the southern part of the hydrozone on the border with the

Table 9 Type of plant communities in marsh hydrozones (Wicik 1995; Michalska-Hejduk et al. 2011)

\begin{tabular}{|c|c|c|c|c|c|}
\hline \multirow[t]{3}{*}{ Community type } & \multicolumn{4}{|l|}{ Area } & \multirow[t]{3}{*}{ Class No } \\
\hline & \multicolumn{2}{|c|}{$\begin{array}{l}\text { Northern } \\
\text { hydrozone }\end{array}$} & \multicolumn{2}{|c|}{$\begin{array}{l}\text { Southern } \\
\text { hydrozone }\end{array}$} & \\
\hline & [\%] & {$\left[\mathrm{km}^{2}\right]$} & [\%] & {$\left[\mathrm{km}^{2}\right]$} & \\
\hline Dry & 19.8 & 30.82 & 14.03 & 12.15 & 1 \\
\hline Mesic and dry & 40.19 & 62.57 & 43.38 & 37.58 & 2 \\
\hline Mesic & $9.9^{\prime}$ & 15.52 & 7.20 & 6.24 & 3 \\
\hline Wet & 30.04 & 46.77 & 35.39 & 30.65 & 4 \\
\hline
\end{tabular}


Blonski Levels. Their contribution was assessed at $14 \%$ of the hydrozone. The mesic plant communities occupy approximately $7 \%$ of the area. Typically wet areas cover $30.65 \mathrm{~km}^{2}$, which constitutes $35.39 \%$ of the area.

\section{Results and discussion}

As a result of the representation of different ranges of values and measures of the particular classes and ranks, a standardization was carried out. Based on the created correlation matrix, strongly correlated elements were determined, whereby these elements were excluded from the analysis. The description of the total variance was premised on seven components - magnitude of recharge, lithology of unsaturated zone, distance from watercourses, soil types, the hydraulic conductivity of the upper part of an aquifer, average annual amplitude, and the type of plant community. The analysis of the principal components allowed, on the basis of the Scree test, for the separation of three factors, explaining $63.47 \%$ of the total variance (Fig. 8; Table 10. The remaining four factors were characterized by an eigenvalue of less than 0.8 .

An attempt at interpretation of the most influential factors in the presented population was undertaken on the basis of the factor loadings of the particular variables grouped within each factor. Loads lower than 0.2 were not taken into account. For factors highlighted in Table 11, the spatial range of impact was specified on the basis of factor values that illustrate the intensity of the impact factor. Four groups were distinguished: $<-0.5$, no factor impact; $-0.5-0.5$, mean impact; $0.5-1.0$, strong impact; $>1$, very strong impact.

The factor 1 accounts for $31.67 \%$ of the population variability. On the basis of factor loadings, it should be recognized that this factor characterizes the generality of the abiotic components of wetland environments, for both hydrogeological and environmental elements. A relationship between these elements within the factor 1 situation indicates significant homogeneity of the characterized system, where regularities commonly occur in every type of environment (such as the dependence of recharge on lithology of subsurface sediments in the unsaturated zone or the depth to groundwater).

Factor scores enable the specification of those areas in marsh hydrozones where there is consistency in abiotic elements and areas where this relationship is not observed. Very strong and strong impacts of factor 1 were found on $35 \%$ of the northern and on $32 \%$ of the southern hydrozone, mainly in the peripheral parts (Fig. 9). Factor 1 does not affect the central part of the hydrozones where a dense discharge network exists that could transform the local discharge conditions leading primarily to long-term and irreversible changes in the structure of soils during the process of organic soil decomposition (Piórkowski et al. 2011). Areas totaling $83.31 \mathrm{~km}^{2}$ with no factor 1 impact occur mainly along main channels - Łasica Channel in the northern hydrozone and along Zaborowski and Olszowiecki channels in the southern hydrozone. The changes in groundwater conditions in these regions are significant, taking into account that before creation of the discharge network almost $99 \%$ of marsh hydrozone areas were occupied by areas without surface outflow (Krogulec 2004). Inconsistency in terms of abiotic elements also occurs in small depressions with no outflow, where the water table is shallow at about $0.3 \mathrm{~m}$ or on the surface forming a temporary overflow area. The statistical analysis of the monitoring data showed that the correlation between groundwater level and the amount of precipitation does not exist in both types of areas (Krogulec et al. 2010), so groundwater levels are affected by other factors, probably related to anthropogenic pressures (decreasing groundwater level caused by the discharge network) or animal activity (increasing groundwater level caused by beaver dams). Both

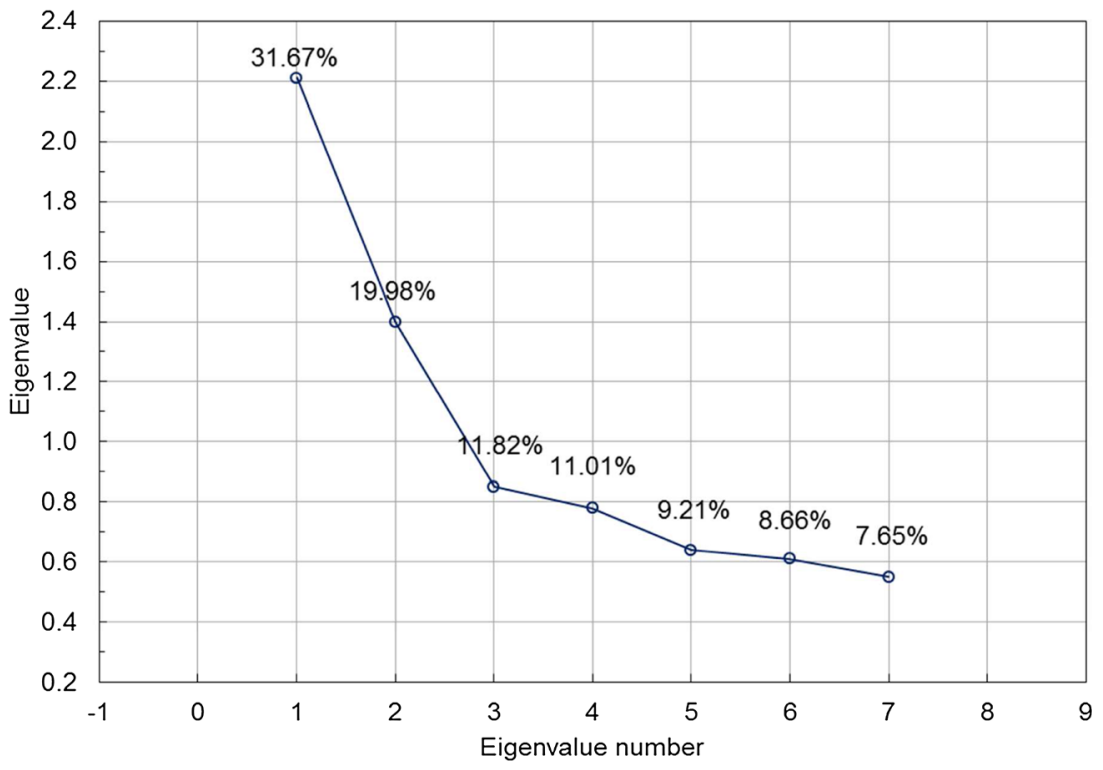

Fig. 8 Scree plot with variance of each factor

Hydrogeology Journal (2015) 23: 1587-1602 


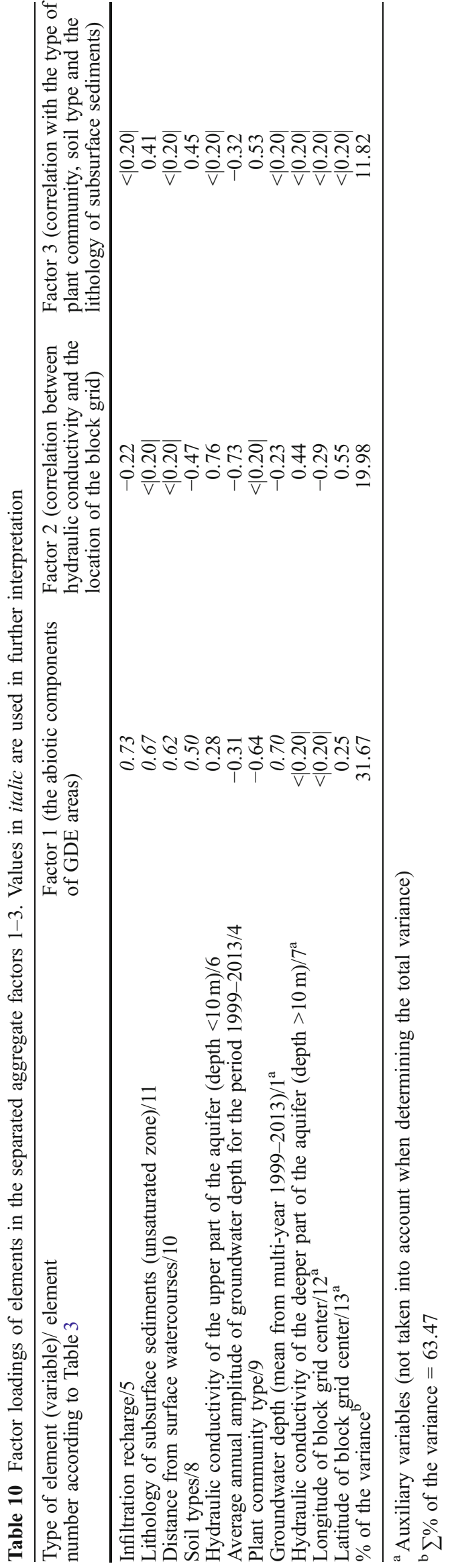

Hydrogeology Journal (2015) 23: 1587-1602 of these factors have been almost constant in the past 15 years, especially in areas of strict protection.

Factor 2 is responsible for approximately $20 \%$ of the population variability. Within this factor, there is a correlation between both hydraulic conductivity data with the longitude of the block center. By grouping these variables in one factor, the belt arrangement characterized by parallel layouts of terrain forms, noticeable in morphology and geomorphology, was emphasized. This dependency concerns both parts of the aquifer: shallow (depth $<10 \mathrm{~m}$ ), which is obvious because it is related to geomorphology forms, but also the deep part of the aquifer, for which total thickness exceeds even $50 \mathrm{~m}$. This phenomenon shows that during the formation of Vistula terraces in previous glacial and interglacial periods, the direction of erosion and accumulation processes was mainly the same-from east to west direction, especially in the area of the northern marsh hydrozone, where the highest factor values occur (approximately $53 \%$ of the area). The areas where the factor does not have an effect account for only $12 \%$. In the southern marsh hydrozone, the intensity of the impact factor is lower-there is only $1.25 \%$ of area with very strong factor impact and almost $59 \%$ of the area has no factor impact. Regarding factor 2, dependency can be invisible in this part of the area because of the vicinity of Blonski Level, which has geological and lithological characteristics that are different compared with the KNP area.

Factor 3 is responsible for about $12 \%$ of the population variability. There is a correlation with the type of plant community, type of soil and the lithology of subsurface sediments in the unsaturated zone. Dependency between plant community and groundwater depth was not found; however, the results point at the important role of the soil type and subsurface lithology in forming plant communities, and these elements are indirectly related with groundwater depth in presented GDE areas.

Several reasons for the lack of dependency identified by factor analysis were found. The first is connected with the changes of hydrogeological conditions due to the discharge network functioning described in the preceding. The second is connected with the high tolerance of vegetation type to the depth of the water table. The range of groundwater level changes resulting from both seasonal changes and sequences of dry and wet years (found in statistical analysis of monitoring data) is equal to the range of tolerance of plant community types (Table 12), even when considered typical for swamps: i.e., Caricetalia fuscae occurring in the peatlands with permanently high groundwater state (Daniels 1982), or Calthion (typically swamp), which is present in the range of an average depth to water table from 0.15 to $0.60 \mathrm{~m}$ (De Becker et al. 1999), Molinion (wet) from 0.1 to $1.3 \mathrm{~m}$ (Jansen et al. 2000), and Arrhenatherion (wet) from 0.4 to $1.2 \mathrm{~m}$ (Kryszak et al. 2008). The third is connected with the areas where no link between the type of plant community, the lithology of subsurface sediments and soil type was found (factor 
Table 11 Participation of spatial occurrence of the factors 1-3 in GDE areas

\begin{tabular}{|c|c|c|c|c|c|c|c|}
\hline \multirow[t]{2}{*}{ Factor score } & \multirow{2}{*}{$\begin{array}{l}\text { Intensity of the } \\
\text { impact factor }\end{array}$} & \multicolumn{2}{|l|}{ Factor 1} & \multicolumn{2}{|l|}{ Factor 2} & \multicolumn{2}{|l|}{ Factor 3} \\
\hline & & $\begin{array}{l}\text { Northern } \\
\text { hydrozone }\end{array}$ & $\begin{array}{l}\text { Southern } \\
\text { hydrozone }\end{array}$ & $\begin{array}{l}\text { Northern } \\
\text { hydrozone }\end{array}$ & $\begin{array}{l}\text { Southern } \\
\text { hydrozone }\end{array}$ & $\begin{array}{l}\text { Northern } \\
\text { hydrozone }\end{array}$ & $\begin{array}{l}\text { Southern } \\
\text { hydrozone }\end{array}$ \\
\hline \multicolumn{8}{|c|}{ Participation of the factor [\%] } \\
\hline$>1.0$ & Very strong impact & 21.01 & 18.48 & 26.31 & 1.25 & 17.79 & 14.48 \\
\hline $0.5-1.0$ & Strong impact & 14.47 & 14.62 & 26.81 & 6.32 & 16.37 & 17.99 \\
\hline$-0.5-0.5$ & Average impact & 34.12 & 25.36 & 34.79 & 33.46 & 32.31 & 37.60 \\
\hline$<-0.5$ & No factor impact & 30.40 & 41.54 & 12.09 & 58.97 & 33.52 & 29.93 \\
\hline \multicolumn{8}{|c|}{ Participation of the factor $\left[\mathrm{km}^{2}\right]$} \\
\hline$>1.0$ & Very strong impact & 32.71 & 16.01 & 40.96 & 1.08 & 27.70 & 12.54 \\
\hline $0.5-1.0$ & Strong impact & 22.53 & 12.66 & 41.74 & 5.47 & 25.48 & 15.58 \\
\hline$-0.5-0.5$ & Average impact & 53.12 & 21.97 & 54.16 & 28.98 & 50.30 & 32.57 \\
\hline$<-0.5$ & No factor impact & 47.33 & 35.98 & 18.82 & 51.08 & 52.18 & 25.93 \\
\hline Area $\left[\mathrm{km}^{2}\right]$ & 155.68 & 86.62 & 155.68 & 86.62 & 155.68 & 86.62 & \\
\hline
\end{tabular}

3 score lower than -0.5$)$. These areas represent about $30 \%$ of both hydrozones, and are associated mainly with plant communities introduced by humans such as agricultural lands, orchards and the vegetation accompanying detached houses, where this kind of dependency cannot be found.

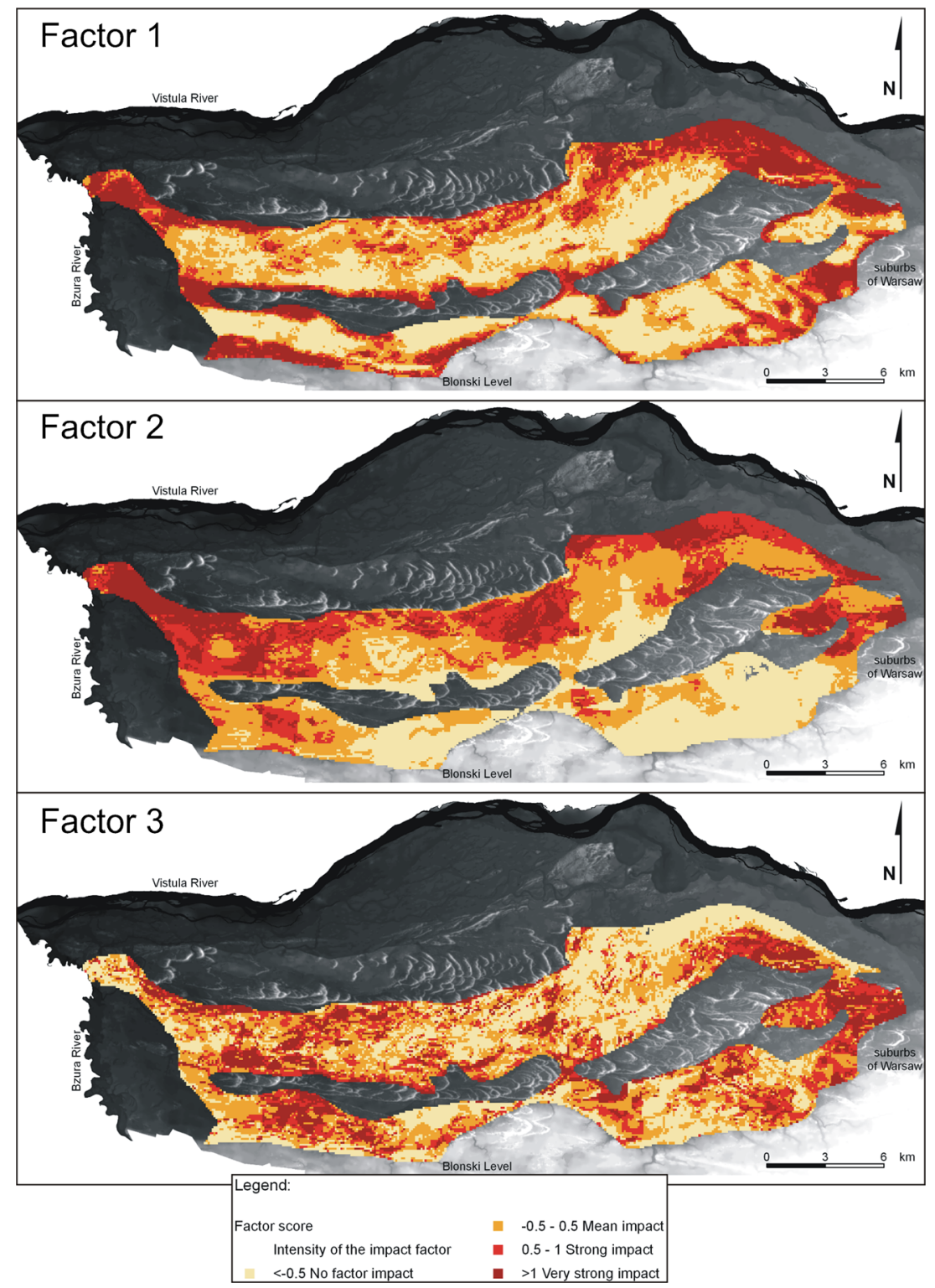

Fig. 9 Spatial development of intensity of the impact factors in the GDE areas 
Table 12 Selected plant communities vs humidity requirements and groundwater $(g w)$ conditions

\begin{tabular}{|c|c|c|c|c|c|}
\hline Plant community & $\begin{array}{l}\text { Groundwater depth } \\
\text { according to the humidity } \\
\text { requirements }[\mathrm{m}]\end{array}$ & $\begin{array}{l}\text { Average annual } \\
\text { gw depth in } \\
1999-2013[\mathrm{~m}]\end{array}$ & $\begin{array}{l}\text { Average annual gw } \\
\text { level amplitude [m] }\end{array}$ & $\begin{array}{l}\text { Average factor } \\
3 \text { score }\end{array}$ & Area $\left[\mathrm{km}^{2}\right]$ \\
\hline $\begin{array}{l}\text { Caricetalia fuscae } \\
\text { (typically swamp) }\end{array}$ & $\begin{array}{l}\text { Permanently near } \\
\text { ground surface }\end{array}$ & 0.33 & 0.80 & -0.06 & 0.46 \\
\hline Calthion (typically swamp) & $0.15-0.60$ & 0.48 & 0.82 & 0.33 & 27.09 \\
\hline Arrhenatherion (typically wet) & $0.40-1.20$ & 0.62 & 0.83 & -0.66 & 1.06 \\
\hline Molinion (typically wet) & $0.10-1.30$ & 1.04 & 0.85 & 0.08 & 0.23 \\
\hline
\end{tabular}

Strong and very strong impacts of factor 3 were found in the western part of the southern hydrozone (33\% of the area, Fig. 9) and in the western and eastern parts of the northern hydrozone (34\%), usually in the peripheral parts of the area (poorly developed soils, typical dune areas) and outside regions, where an extensive discharge network had been created (peat and marsh soils dominate).

\section{Conclusions}

Statistical analysis of the point monitoring data enabled a determination of the scope of the groundwater level changes in the period 1999-2013, and in the annual and seasonal periods. It was found that in 2003 and 2011 there were, respectively, the lowest and highest levels of groundwater. The range of changes was from $0.40 \mathrm{~m}$ above ground surface (2011) to $2.16 \mathrm{mbgs}$ (2003) in the northern hydrozone, and from $0.83 \mathrm{~m}$ above ground surface (2011) to $3.17 \mathrm{mbgs}$ (2006) in the southern hydrozone. Seasonal changes proceed in a similar manner in the whole period from 1999 to 2013. There were no specific trends in the depth to water table, which resulted in the occurrence of a sequence of dry and wet years in this period. This statistical analysis, which was possible to conduct on the basis of available monitoring data concerning groundwater levels, does not confirm the common belief of a lowering water table in presented GDEs due to anthropogenic pressure and climate change. There were no long-term changes in groundwater levels over this time period.

The spatial distribution of groundwater depth enabled the visualization of the characteristic maximum and minimum depth to groundwater within the marsh hydrozones. During the lowest groundwater levels occurring in 2003 in the northern marsh hydrozone, water was present beneath the surface only across $0.39 \mathrm{~km}^{2}$, but in the period of the highest groundwater levels (2011) approximately $81 \mathrm{~km}^{2}$ of the area was flooded. In the same year, in the southern marsh hydrozone approximately $40.1 \mathrm{~km}^{2}$ was flooded (water table above the surface).

The factor analysis of PCA enables, after the wide recognition of the generality of hydrogeological and environmental elements, the grouping of the variables to the newly created factors and their merit interpretation on the basis of factor loadings. The factor analysis showed that the marsh hydrozone areas are characterized by a considerable homogeneity of abiotic elements occurring in factor 1. There are heterogeneous regions within the hydrozones, which are associated with the presence of a dense discharge network or the occurrence of numerous depressions with no outflow, where hydrogeological and environmental conditions are highly variable in relation to the total area. The PCA method indicated that the spatial distribution of hydraulic conductivity is related to characteristic geomorphological forms occurring on the surface. This dependency concerns both parts of the aquifer: shallow (depth $<10 \mathrm{~m}$ ) and deep (from 10 to $50 \mathrm{~m}$ ). Dependency between the type of plant community and depth to the water table in the typical GDEs was not defined by the delimiting factors. The type of plant community vs depth to water-table relation considered as typical for GDEs, was not defined by the delimitated factors (1-3). The reasons that this dependence may not be visible are: discharge-network functioning, smaller groundwater-level changes than is tolerated by the particular plant communities (average annual amplitude does not exceed $1 \mathrm{~m}$ ), or the existence of types of plant communities related to human activity (agricultural lands, orchards and the vegetation accompanying detached houses). Although dependence was not found, presented marsh hydrozones are groundwater-dependent ecosystems, which was confirmed by the occurrence of typical plant communities with high humidity requirements. These requirements were expressed by high correlation with soil type and lithology of subsurface sediments. Their formation was also related with shallow water-table occurrence.

Acknowledgements This work was supported by the National Research Council (grant number N N525253940) and statutory research of the Faculty of Geology, University of Warsaw, Poland.

Open Access This article is distributed under the terms of the Creative Commons Attribution 4.0 International License (http:// creativecommons.org/licenses/by/4.0/), which permits unrestricted use, distribution, and reproduction in any medium, provided you give appropriate credit to the original author(s) and the source, provide a link to the Creative Commons license, and indicate if changes were made.

\section{References}

Aller L, Bennett T, Lehr JH, Petty RJ, Hackett G (1987) DRASTIC: a standardized system of evaluating ground water pollution potential using hydrogeological settings. EPA no. 600287035, USEPA, Washington, DC 
Baalousha H (2010) Assessment of a groundwater quality monitoring network using vulnerability mapping and geostatistics: a case study from Heretaunga Plains, New Zealand. Agric Water Manag 97(2):240-246

Baattrup-Pedersen A, Andersen HE, Larsen SE, Nygaard B, Ejrnaes R (2012) Predictive modelling of protected habitats in riparian areas from catchment characteristic. Ecol Indic 18:227-235

Babiker IS, Mohamed MAA, Hiyama T, Kato K (2005) A GISbased DRASTIC model for assessing aquifer vulnerability in Kakamigahara Heights, Gifu Prefecture, central Japan. Sci Total Environ 345(1-3):127-140

Baker ME, Wiley MJ, Seelbach PW (2001) GIS-based hydrologic modeling of Riparian areas: implications for stream water quality. J Am Water Resour Assoc 37:1615-1628

Baraniecka DM, Konecka-Betley K (1987) Fluvial sediments of the Vistulian and Holocene of the Warsaw basin. Geogr Stud 4:151-170

Bidwell VJ (2005) Realistic forecasting of groundwater level, based on the eigenstructure of aquifer dynamics. Math Comput Simul 69(1-2):12-20

Boulton AJ (2005) Chances and challenges in the conservation of groundwaters and their dependent ecosystems. Aquat Conserv 15:319-323

Boulton AJ, Hancock PJ (2006) Rivers as groundwater-dependent ecosystems: a review of degrees of dependency, riverine processes and management implications. Aust J Bot 54:133-144

Bryant EH, Atchley WR (1975) Multivariate statistical methods, within-groups covariation. Dowden, Hutchins \& Ross, Stroudsburg, PA

Cattell RB (1966) The Scree test for the number of factors. Multivar Behav Res 1:245-276

Coppola E, Rana A, Poulton M, Szidarovszky F, Uhl V (2005) A neural network model for predicting aquifer water level elevations. Ground Water 43(2):231-241

Daniels JFA (1982) Vegetation of the Angmagssalik District, southeast Greenland, IV: shrub, dward shrub and terricolous lichens. Bioscience 10, Museum Tusculanum Press, Copenhagen

De Becker P, Hermy M, Butaye J (1999) Ecohydrological characterization of a groundwater-fed alluvial floodplain mire. Appl Veg Sci 2:215-228

Dragon K (2002) Application of factor analysis to determine the anthropogenic changes in groundwater quality (in Polish). Prz Geol 50(2):127-131

Dzierżek J (ed) (2001) Sculpture and Quaternary deposits of central Poland: class field guide of geomorphology and Quaternary geology (in Polish). University of Warsaw, Warsaw

Eamus D, Hatton T, Cook P, Colvin C (2006) Ecohydrology: vegetation function, water and resource management. CISRO, Collingwood, Australia

Gangopadhyay S, Das Gupta A, Nachabe MH (2001) Evaluation of ground water monitoring network by principal component analysis. Groundwater 39(2):181-191

Gogu R, Carabin G, Hallet V, Peters V, Dassargues A (2001) GISbased hydrogeological databases and groundwater modelling. Hydrogeol J 9(6):555-569

Gruszczyński T, Krogulec E (2012) Selection of the renaturalization variant of wetlands in Kampinos National Park based on hydrodynamic model tests (in Polish). Biul Inst Geol Tom 451:45-52

Jansen AJM, Grootjans AP, Jalink MH (2000) Hydrology of Dutch Cirsio-Molinietum meadows: prospects for restoration. Appl Veg Sci 3:51-64

Jolliffe IT (2002) Principal component analysis, 2nd edn. Springer, New York

Joreskog KG, Klovan JE, Reyment RA (1976) Geological factor analysis. Elsevier, Amsterdam

Kloss M (2003a) Rushes and peat communities (in Polish). In Andrzejewski R (ed) Nature of Kampinoski National Park. Kampinos National Park, Izabelin, Poland, pp 315-338

Kloss M (2003b) Forest and scrub communities (in Polish). In: Andrzejewski R (ed) Nature of Kampinoski National Park. Kampinos National Park, Izabelin, Poland, pp 285-314
Klove B, Ala-aho P, Bertrand G, Boukalova Z, Ertuk A, Goldscheider N, Ilmonen J, Karakaya N, Kupferberger H, Kverner J, Kundberg A, Mileusnic M, Moszczynska A, Muotka T, Preda E, Rossi P, Sergieiew D, Simek J, Wachniew P, Angheluta V, Widerlund A (2011) Groundwater dependent ecosystems, part I: hydroecological status and trends. Environ Sci Policy 14:770-781

Kopeć D, Michalska-Hejduk D, Krogulec E (2013) The relationship between vegetation and groundwater levels as an indicator of spontaneous wetland restoration. Ecol Eng 57:242-251

Krogulec E (1997) Numerical analysis of the structure of the filtration flux in the edge zone of Blonski level (in Polish). Uniwersytetu Warszawskiego, Warsaw

Krogulec E (2003a) Evaluation of hydrogeological conditions based on modelling: a case study in the Kampinos National Park region, central Poland. Geol Q 47(1):83-90

Krogulec E (2003b) Hydrological conditions of the Kampinoski National Park (KNP) region. Ecohydrol Hydrobiol Tom 3(Nr 3 r):257-266

Krogulec E (2004) Vulnerability assessment of groundwater pollution in the river valley on the basis of hydrodynamic evidence (in Polish). Uniwersytetu Warszawskiego, Warszawa

Krogulec E (2013) Intrinsic and specific vulnerability of groundwater in a river valley: assessment, verification and analysis of uncertainty. J Earth Sci Clim Chang 4(6). 10.4172/2157$7617.1000159 / 1-12$

Krogulec E, Zabłocki S (2008) Geostatistical analysis of groundwater conditions in Kampinoski National Park (in Polish). Instytut Geografii i Gospodarki Przestrzennej Uniwersytetu Jagiellońskiego, Ojcowski Park Narodowy i Komisja Hydrologiczna Polskiego Towarzystwa Geograficznego, Kraków, pp 189-200

Krogulec E, Pomianowski P, Krogulec P (2003) Results of geophysical research in the Kampinos National Park central part. Ecohydrol Hydrobiol 3(3):267-272

Krogulec E, Andrzejewska A, Furmankowska A, Zabłocki S (2009) Analysis of groundwater level in wetland areas on the basis of observations in Kampinos National Park (in Polish). Biul Panstw Inst Geol 436(IX/1):281-288

Krogulec E, Furmankowska A, Trzeciak J, Zabłocki S (2010) Factors determining range and tendencies of groundwater level changes in Kampinos National Park wetland areas. Biul Inst Geol 441:73-82

Krogulec E, Furmankowska A, Jóźwiak K, Zabłocki S (2011) Range and tendencies of groundwater level changes in wetland areas of Kampinos National Park (in Polish). Woda Środowisko-Obszary Wiejskie 11(3):99-112

Kryszak A, Kryszak J, Klarzyńska A (2008) The effect of habitat conditions and utilisation on the development of Arrhenatheretum elatioris. Water Environ Rural Areas 8(1):175-184

Kucharski L, Michalska-Hejduk D (2003) Meadow and sward communities (in Polish). In: Andrzejewski R (ed) Nature of Kampinoski National Park. Kampinos National Park, Izabelin, Poland, pp 339-360

Liszkowska E (1995) Factor analysis as an objective method for determining the origin of the chemical composition and sources of groundwater pollution (in Polish). Wspólczesne Ploblemy Hydrogeol 7(2):329-335

Loaiciga H, Charbeneau R, Everett L, Fogg G, Hobbs B, Rouhani S (1992) Review of ground-water quality monitoring network design. J Hydraul Eng 118(1):11-37

Maheswaran R, Khosa R (2013) Long term forecasting of groundwater levels with evidence of non-stationary and nonlinear characteristics. Comput Geosci 52:422-436

Michalska-Hejduk D, Kopeć D, Kucharski L, Kębłowska A, Otręba A, Kloss M, Dembek A (2011) Vegetation of wetland areas: current state and dynamical tendencies (in Polish). In: Okruszko T, Mioduszewski W, Kucharski L (eds) Protection and restoration of wetlands in Kampinos National Park. Wydawnictwo SGGW, Warsaw, pp 119-142

Moon S, Woo NC, Lee KS (2004) Statistical analysis of hydrographs and water-table fluctuation to estimate groundwater recharge. J Hydrol 292(1-4):198-209 
Murray B, Hose GC, Eamus D, Licari D (2006) The valuation of groundwater-dependent ecosystems: a functional methodology incorporating ecosystem services. Aust J Bot 54:221-229

Olivera F, Maidment D (1999) Geographic Information Systems (GIS)-based spatially distributed model for runoff routing. Water Resour Res 35(4):1155-1164

Piórkowski H, Domańska M, Rycharski M, Jakubowski W, Stefaniak P (2011) Soils of wetland areas. In: Okruszko T, Mioduszewski W, Kucharski L (eds) Protection and restoration of wetlands in Kampinos National Park. Wydawnictwo SGGW, Warsaw, pp 93-118

Reyment RA, Joreskog KG (1993) Applied factor analysis in the natural sciences. Cambridge Univ Press, Cambridge

Sarnacka Z (1992) Stratigraphy of Quaternary sediments: Warsaw and surrounding areas (in Polish). Pr Panstw Inst Geol 138:1-36

Shiri J, Kisi O, Yoon H, Lee K, Nazemi AH (2013) Predicting groundwater level fluctuations with meteorological effect implications: a comparative study among soft computing techniques. Comput Geosci 56:32-44

Sikorska-Maykowska M, Krogulec E, Fic M (1998) Hydrogeological documentation from piezometers made with monitoring programme in the area of Kampinos National Park and its protection zone (in Polish). Aquageo - Michał Fic, Warsaw
Soczyńska U, Gutry-Korycka M, Pokojska P, Mikos D (2003) Potamology balance as a method of variation of water circulation in the Lasica basin (KNP). Ecohydrol Hydrobiol 3(3): s.291-309

Stępień M (2004) Processes and hydrogeological conditions in the area of Krzeszowice basin and its vicinity (middle Sudetes) (in Polish). PhD Thesis, Uniwersytet Warszawski, Warsaw, Poland

Store R, Kangas J (2001) Integrating spatial multi-criteria evaluation and expert knowledge for GIS-based habitat suitability modelling. Landsc Urban Plan 55(2):79-93

Tóth J (1963) A theoretical analysis of groundwater flow in small drainage basins. J Geophys Res 68(16):4795-4812

Whiteman M, Brooks A, Skinner A, Hulme P (2010) Determining significant damage to groundwater-dependent terrestrial ecosystems in England and Wales for use in implementation of the Water Framework Directive. Ecol Eng 36:1118-1125

Wicik B (1995) Protection plan of Kampinos National Park (in Polish). Soils. Arch. KPN, Izabelin

Yang F, Cao S, Liu X, Yang K (2008) Design of groundwater level monitoring network with ordinary kriging. J Hydrodyn Ser B 20(3):339-346 